\title{
Special issue on the battle against complex virus world in the human brain: seizure as a result of viral infection
}

\author{
Weijia Jiang ${ }^{1}$, Jinmei $\mathrm{Li}^{2}$, Dong Zhou ${ }^{2}$ and Jie $\mathrm{Mu}^{2^{*}}$
}

Viruses are the smallest living things known to science, yet they hold the entire planet in their way.

- from A Planet of Viruses, Carl Zimmer

The corona virus disease 2019 (COVID-19) pandemic, caused by severe acute respiratory syndrome coronavirus 2 (SARS-CoV-2), has become a big threat to human health. Studies have shown that SARS-CoV-2 can also invade the central nervous system (CNS) [1]. Currently, it remains unclear if SARS-CoV-2 infection could cause status epilepticus [2]. However, some viruses or their sub-classes have been known to cause brain damage, which would then initiate or worsen seizure attacks (Table 1). A comprehensive understanding of the relationship between viral infection and seizure would provide insight into the effects of SARS-CoV-2 on seizures, in this particular COVID-19 crisis. In this special issue, we provide a collection of papers discussing on the following questions: which viruses can induce epileptic seizures? In what way do viruses invade human body? What are the vectors for different viruses? Is seizure directly caused by a virus or indirectly induced by immune response? What are the seizure features and electroencephalogram findings after virus infection? What is the treatment and prognosis for viral infection? Can we develop specific vaccines for viral infection?

Acta Epileptologica is an international academic journal that publishes advances in epileptic research. Viruses are an important cause for seizures. To highlight the important roles of viruses in epilepsy, especially under the current COVID-19 pandemic, Acta Epileptologica publishes this special issue on "Virus and Epilepsy", focusing

\footnotetext{
* Correspondence: mujie2010@foxmail.com

${ }^{2}$ Neurology Department, West China Hospital of Sichuan University, 14\# Third Section, Renmin Nan Road, Chengdu 610041, China

Full list of author information is available at the end of the article
}

on four viruses: arbovirus, human immunodeficiency virus (HIV), picornavirus, and human herpes virus 6 (HHV6), from perspectives of pathogenesis, pathogenicity, clinical characteristics, treatment, and prognosis of seizure induction or enhancement after viral infection. Most importantly, the mechanisms underlying viral association with epileptogenesis are also discussed.

In the paper entitled "Arbovirus and seizures", Mingrui Zheng et al. summarized the most common arboviruses associated with epidemic viral encephalitis. Viral encephalitis affects both children and adults, usually leading to severe neurological sequelae. Arboviruses of the genus Flavivirus are usually transmitted by mosquitoes and other host animals. Among various arboviruses, the Japanese encephalitis virus, West Nile virus, Zika virus, Dengue virus and Chikungunya virus can induce seizures. Seizures may not be the major manifestation, but may predict a poor prognosis. The occurrence of seizure is mainly caused by direct cell damage by the virus, secondary glial and immune responses producing inflammatory cytokines, and damage to the blood-brain barrier. Different virus infections may lead to mild or severe symptoms, with varied occurrence of epilepsy. The seizure type can usually be focal or generalized, or even status epilepticus. The generalized tonic-clonic seizures are the most common type. EEG recordings have consistently found a pattern of diffuse slow activity. During occurrence of seizure, patients typically manifest with abnormalities including theta and delta coma, burst suppression, an isoelectric pattern, or occasionally alpha coma. Effective treatment of associated epileptic seizures, mostly symptomatic support and anti-virus therapy, enables good supportive care and optimal control of CNS-related comorbidities. However, usually there is a lack of effective treatment methods.(https://aepi.

(c) The Author(s). 2021 Open Access This article is licensed under a Creative Commons Attribution 4.0 International License, which permits use, sharing, adaptation, distribution and reproduction in any medium or format, as long as you give appropriate credit to the original author(s) and the source, provide a link to the Creative Commons licence, and indicate if changes were made. The images or other third party material in this article are included in the article's Creative Commons licence, unless indicated otherwise in a credit line to the material. If material is not included in the article's Creative Commons licence and your intended use is not permitted by statutory regulation or exceeds the permitted use, you will need to obtain permission directly from the copyright holder. To view a copy of this licence, visit http://creativecommons.org/licenses/by/4.0/. 
Table 1 The typical viruses associated with seizures and features of resulting seizures in humans or animal models

\begin{tabular}{|c|c|c|}
\hline Virus family & Typical seizure related virus & Seizure features \\
\hline \multicolumn{3}{|l|}{ RNA virus: } \\
\hline \multirow[t]{2}{*}{ Flaviviridae } & $\begin{array}{l}\text { West Nile virus, Japanese encephalitis virus, St Louis Encephalitis virus, Dengue } \\
\text { viruses (types 1-4), Tick-borne encephalitis virus }\end{array}$ & $\begin{array}{l}\text { Generalized tonic-clonic seizures; } \\
\text { Partial motor with secondary generalization; } \\
\text { Non-convulsive and convulsive status epilepticus } \\
\text { [3]; } \\
\text { Acute flaccid paralysis [4] }\end{array}$ \\
\hline & Zika virus & Early and refractory epilepsy [5] \\
\hline Bunyaviridae & La Crosse virus & $\begin{array}{l}\text { Complex partial or simple partial focal seizure; } \\
\text { Periodic epileptiform discharges [6] }\end{array}$ \\
\hline Orthomyxoviridae & Influenza virus & $\begin{array}{l}\text { Generalized tonic-clonic seizures; } \\
\text { Convulsive status epilepticus [3]; } \\
\text { Febrile seizures [7] }\end{array}$ \\
\hline \multirow[t]{3}{*}{ Paramyxoviridae } & Mumps virus & $\begin{array}{l}\text { Generalized tonic-clonic seizures [3]; } \\
\text { Acute flaccid paralysis [4] }\end{array}$ \\
\hline & Measles virus, Canine distemper virus & Generalized tonic-clonic seizures [3] \\
\hline & Nipah virus & Convulsive status seizures [8] \\
\hline \multirow[t]{2}{*}{ Rhabdoviridae } & Rabies virus & $\begin{array}{l}\text { Generalized tonic-clonic seizures [3]; } \\
\text { Febrile seizure [9]; } \\
\text { Focal facial and limb seizures [10]; } \\
\text { Acute flaccid paralysis [4] }\end{array}$ \\
\hline & Chandipura virus & $\begin{array}{l}\text { Generalized tonic-clonic seizures; } \\
\text { Focal seizure [11] }\end{array}$ \\
\hline Retroviridae & Human immunodeficiency virus & $\begin{array}{l}\text { Generalized tonic-clonic seizures; } \\
\text { Partial motor with/without secondary } \\
\text { generalization; Atonic seizures; } \\
\text { Non-convulsive and convulsive status epilepticus; } \\
\text { High incidence of recurrence [3] }\end{array}$ \\
\hline \multirow[t]{4}{*}{ Picornaviridae } & Enterovirus 70 & $\begin{array}{l}\text { Generalized tonic-clonic seizures [3] } \\
\text { Complex partial or simple partial focal seizure [6] } \\
\text { Febrile seizure [12] }\end{array}$ \\
\hline & Enterovirus 71 & $\begin{array}{l}\text { Complex partial or simple partial focal seizure [6] } \\
\text { Febrile seizure [12] }\end{array}$ \\
\hline & Poliovirus & Acute flaccid paralysis [4] \\
\hline & Rhinovirus & Febrile seizure [12] \\
\hline Togaviridae & Eastern equine encephalitis viruses & $\begin{array}{l}\text { Complex partial or simple partial focal seizure; } \\
\text { Periodic epileptiform discharges [6] }\end{array}$ \\
\hline Reoviridae & Rotavirus & Febrile seizures [13] \\
\hline Paramyxoviridae & Human parainfluenza viruses & Febrile seizures [13] \\
\hline \multirow[t]{3}{*}{ Coronaviridae } & Severe acute respiratory syndrome coronavirus & $\begin{array}{l}\text { Abnormity located in the temporal lobe } \\
\text { accompanied with seizures [14]; } \\
\text { Refractory status epilepticus [15] }\end{array}$ \\
\hline & $\begin{array}{l}\text { Middle East respiratory syndrome-related coronavirus, Human coronavirus } \\
\text { OC43, Human coronavirus HKU1 }\end{array}$ & Febrile seizures [16] \\
\hline & Severe acute respiratory syndrome coronavirus 2 & Focal seizure [17] \\
\hline \multirow[t]{2}{*}{ Pneumoviridae } & Respiratory syncytial virus/orthopneumovirus & $\begin{array}{l}\text { Febrile seizure [12]; } \\
\text { Status epilepticus [15] }\end{array}$ \\
\hline & Human metapneumovirus & $\begin{array}{l}\text { Focal seizure; } \\
\text { Status epilepticus [15]; } \\
\text { Febrile seizures [13] }\end{array}$ \\
\hline Caliciviridae & Norovirus & Febrile seizures [13] \\
\hline Astroviridae & Astrovirus & Febrile seizures [13] \\
\hline \multicolumn{3}{|l|}{ DNA virus: } \\
\hline Herpesviridae & $\begin{array}{l}\text { Herpes simplex type } 1 \text {, } \\
\text { Herpes simplex type } 2\end{array}$ & $\begin{array}{l}\text { Generalized tonic-clonic seizures; } \\
\text { Complex partial seizures; Non-convulsive and }\end{array}$ \\
\hline
\end{tabular}


Table 1 The typical viruses associated with seizures and features of resulting seizures in humans or animal models (Continued)

\begin{tabular}{|c|c|c|}
\hline Virus family & Typical seizure related virus & Seizure features \\
\hline & & $\begin{array}{l}\text { convulsive status epilepticus [3]; } \\
\text { Periodic epileptiform discharges; Complex partial } \\
\text { or simple partial focal seizure [6] }\end{array}$ \\
\hline & Human herpes virus 6 & $\begin{array}{l}\text { Generalized tonic-clonic seizures [3]; } \\
\text { Febrile seizures and hippocampal sclerosis [18]; } \\
\text { Often partial seizures, prolonged seizures, and } \\
\text { repeated seizures [19] }\end{array}$ \\
\hline & Cytomegalovirus & $\begin{array}{l}\text { Generalized tonic-clonic Seizures; } \\
\text { Complex partial seizures; } \\
\text { Non-convulsive and convulsive status epilepticus } \\
{[3]}\end{array}$ \\
\hline & Epstein-Barr virus & $\begin{array}{l}\text { Generalized tonic-clonic seizures; } \\
\text { Complex partial seizures; Non-convulsive and con- } \\
\text { vulsive status epilepticus [3] }\end{array}$ \\
\hline Adenoviridae & Adenovirus & $\begin{array}{l}\text { Acute flaccid paralysis }[4] \\
\text { Febrile seizure [12] }\end{array}$ \\
\hline Parvoviridae & Bocaparvovirus & Febrile seizure [12] \\
\hline
\end{tabular}

biomedcentral.com/articles/10.1186/s42494-020-00026w).

In the paper entitled "The role of picornavirus infection in epileptogenesis", Runxuan Zhang et al. summarized the clinical characteristics of picornavirus infection, and the pathogenesis of Theiler's murine encephalomyelitis virus (TMEV)-induced epilepsy. Picornaviruses are a family of small positivestrand RNA viruses and transmitted via the respiratory or fecal-oral route. The neurotropic picornaviruses can induce acute or late recurrent seizures following CNS infection, by infecting the peripheral nerve, crossing the blood-brain barrier and migrating in the Trojan-horse approach. TMEV, as a member of the Picornavirus family, can cause encephalitis, leading to chronic spontaneous seizures. The TMEVinfected animal model has been used to study the mechanisms of epileptogenesis and to evaluate drug efficacy. Several immune components are involved in TMEV-induced epileptogenesis. Minocycline (MIN) treatment can positively affect the long-term epileptogenic process. Valproic acid has a neuroprotection effect through inhibition of histone deacetylase activity, thereby reducing seizures. Conversely, Carbamazepine may exacerbate TMEV infection, making animals more susceptible to the virus. Wogonin can decrease epileptic episodes by inhibiting the activated macrophages targeted by the IL- 6 producing cells in mice. (https://aepi.biomedcentral. com/articles/10.1186/s42494-021-00040-6).

HHV-6 is a ubiquitous and most common pathogen that affects humans. In the paper entitled "Temporal lobe epilepsy associated with human herpes virus 6", Jiaqi
Wang et al. summarized the close relationship between HHV-6B and temporal lobe epilepsy (TLE). The special target of HHV-6 is in the hippocampus and amygdala. Recently, viral genomic DNA of HHV$6 \mathrm{~B}$ has been detected in surgically removed brain tissues of intractable epilepsy patients, suggesting the involvement of HHV-6B in the pathogenesis of epilepsy. TLE patients with HHV-6B in their brains suffer from reiterative attacks of febrile seizures and hippocampal sclerosis. In this article, the potential involvement of cytokines in the pathological process of TLE is reviewed in detail. Anti-inflammatory or immunomodulatory therapies may show prospects for TLE treatment. (https://aepi.biomedcentral.com/articles/1 0.1186/s42494-021-00044-2).

The article entitled "Current epidemiological and etiological characteristics and treatment of seizures or epilepsy in patients with HIV infection" by Changhao $\mathrm{Yu}$ et al. carefully reviewed the role of HIV infection in epilepsy. Opportunistic infections are a stereotypical predisposing factor for seizures in HIV patients. There is a prevalence of $2-19.8 \%$ and an incidence of $1.8-19.8 \%$ for seizures in the HIV-infected population, which are mostly of the generalized type. HIV patients with seizures need to take both antiviral and antiepileptic drugs, which increases the risk of drugdrug interactions and the occurrence of side effects. Antiepileptic drugs should be carefully selected to avoid the CYP450-induced drug-drug interactions. This review further gives a perspective on future therapeutic studies in HIV patients with seizures. (https://aepi.biomedcentral.com/articles/10.1186/s424 94-020-00028-8). 


\section{Abbreviations}

CNS: Central nervous system; COVID-19: Corona virus disease 2019; SARSCoV-2: Severe acute respiratory syndrome coronavirus 2;

EEG: Electroencephalogram; TMEV: Theiler's murine encephalomyelitis virus; MIN: Minocycline; VPA: Valproic acid; HDAC: Histone deacetylase; HHV6: Human herpes virus 6; TLE: Temporal lobe epilepsy; HIV: Human immunodeficiency virus; CBZ: Carbamazepine

\section{Acknowledgements}

Not applicable.

\section{Authors' contributions}

WJJ and JM drafted the manuscript, JML and DZ revised the manuscript. Al authors read and approved the final manuscript.

\section{Funding}

This work was supported by the project Science \& Technology Department of Sichuan Province named the mechanism of inflammatory network induced by HHV-6B/HHV-7 infection in resistent MTLE (NO.2019YFH0145); Sichuan University Postdoctoral Interdisciplinary Innovation Startup Foundation (NO.0040104153001); Science and Technology Activities for Overseas Returnees in Sichuan Province in 2020 (NO.CRSH2020291-18).

\section{Availability of data and materials}

Not applicable.

\section{Declarations}

Ethics approval and consent to participate

Not applicable.

\section{Consent for publication}

All authors gave consent to publication of this review.

\section{Competing interests}

WJJ, JM and DZ are editorial staff of Acta Epileptologica. WJJ is the editor, JM is the managing editor, and DZ is the associate editor.

\section{Author details}

'West China Medical Publishers, West China Hospital of Sichuan University, 14\# Third Section, Renmin Nan Road, Chengdu 610041, China. ${ }^{2}$ Neurology Department, West China Hospital of Sichuan University, 14\# Third Section, Renmin Nan Road, Chengdu 610041, China.

Published online: 16 July 2021

\section{References}

1. Wu Y, Xu X, Chen Z, Duan J, Hashimoto K, Yang L, et al. Nervous system involvement after infection with COVID-19 and other coronaviruses. Brain, behavior, and immunity. 2020;87:18-22. https://doi.org/10.1016/j.bbi.2020.03. 031.

2. Lu L, Weixi $X$, Dan $L$, Jing $L$, Dan $Y$, Nian $L$, et al. New onset acute symptomatic seizure and risk factors in coronavirus disease 2019: A retrospective multicenter study. Epilepsia. 2020;61(6):e49-53. https://doi. org/10.1111/epi.16524.

3. Getts DR, Balcar VJ, Matsumoto I, Müller M, King NJ. Viruses and the immune system: their roles in seizure cascade development. J Neurochem. 2008;104(5):1167-76. https://doi.org/10.1111/j.1471-4159.2007.05171.x.

4. Bayrakdar F, Coşgun Y, Salman Atak T, Karademir H, Korukluoğlu G. Akut flask paralizi şüpheli olguların dışkı örneklerinden adenovirus izolasyon sıklığının araştırıması [Investigation of adenovirus isolation frequency from the stool samples of patients suspected with acute flaccid paralysis]. Mikrobiyol Bul. 2016;50(2):287-92. https://doi.org/10.5578/mb.23142.

5. Nunes ML, Esper NB, Franco AR, Radaelli G, Soder RB, Bomfim R, et al. Epilepsy after congenital zika virus infection: EEG and neuroimaging features. Seizure. 2021;84:14-22. https://doi.org/10.1016/j.seizure.2020.11.004.

6. Bale JF Jr. Virus and immune-mediated Encephalitides: epidemiology, diagnosis, treatment, and prevention. Pediatr Neurol. 2015;53(1):3-12. https://doi.org/10.1016/j.pediatrneurol.2015.03.013.

7. McEntire CRS, Song KW, McInnis RP, Rhee JY, Young M, Williams E, et al. Neurologic manifestations of the World Health Organization's list of pandemic and epidemic diseases. Front Neurol. 2021;12:634827. https://doi. org/10.3389/fneur.2021.634827.

8. Singh RK, Dhama K, Chakraborty S, Tiwari R, Natesan S, Khandia R, Munjal A, Vora KS, Latheef SK, Karthik K, Singh Malik Y, Singh R, Chaicumpa W, Mourya DT. Nipah virus: epidemiology, pathology, immunobiology and advances in diagnosis, vaccine designing and control strategies - a comprehensive review. The veterinary quarterly. 2019;39(1):26-55. https://doi.org/10.1080/01 652176.2019 .1580827$.

9. Tinsa F, Borgi A, Jahouat I, Boussetta K. Rabies encephalitis in a child: a failure of rabies post exposure prophylaxis? BMJ Case Rep. 2015;2015: bcr2014206191.

10. Barnes HL, Chrisman CL, Farina L, Detrisac CJ. Clinical evaluation of rabies virus meningoencephalomyelitis in a dog. J Am Anim Hosp Assoc. 2003; 39(6):547-50. https://doi.org/10.5326/0390547.

11. Narasimha Rao S, Wairagkar NS, Murali Mohan V, Khetan M, Somarathi S. BrainStem encephalitis associated with chandipura in Andhra Pradesh outbreak. J Trop Pediatr. 2008;54(1):25-30.

12. Carman KB, Calik M, Karal Y, Isikay S, Kocak O, Ozcelik A, et al. Viral etiological causes of febrile seizures for respiratory pathogens (EFES study). Hum Vaccin Immunother. 2019;15(2):496-502. https://doi.org/10.1080/2164 5515.2018 .1526588 .

13. Han DH, Kim SY, Lee NM, Yi DY, Yun SW, Lim IS, et al. Seasonal distribution of febrile seizure and the relationship with respiratory and enteric viruses in Korean children based on nationwide registry data. Seizure. 2019:73:9-13. https://doi.org/10.1016/j.seizure.2019.10.008.

14. Li Y, Li H, Fan R, Wen B, Zhang J, Cao X, et al. Coronavirus infections in the central nervous system and respiratory tract show distinct features in hospitalized children. Intervirology. 2016;59(3):163-9. https://doi.org/10.11 59/000453066.

15. Robinson CP, Busl KM. Neurologic manifestations of severe respiratory viral contagions. Crit Care Explor. 2020;2(4):e0107. https://doi.org/10.1097/CCE. 0000000000000107

16. Asadi-Pooya AA. Seizures associated with coronavirus infections. Seizure. 2020;79:49-52. https://doi.org/10.1016/j.seizure.2020.05.005 Epub 2020 May 11.

17. Romero-Sánchez CM, Díaz-Maroto I, Fernández-Díaz E, Sánchez-Larsen Á, Layos-Romero A, García-García J, et al. Neurologic manifestations in hospitalized patients with COVID-19: the ALBACOVID registry. Neurology. 2020;95(8):e1060-70. https://doi.org/10.1212/WNL.0000000000009937.

18. Wang J, Li J. Temporal lobe epilepsy associated with human herpes virus 6 . Acta Epileptologica. 2021;3(1):10. https://doi.org/10.1186/s42494-02100044-2.

19. Houshmandi MM, Moayedi A, Rahmati MB, Nazemi A, Fakhrai D, Zare S. Human herpes virus type 6 and febrile convulsion. Iran J Child Neurol. 2015; 9(4):10-4.
Ready to submit your research? Choose BMC and benefit from:

- fast, convenient online submission

- thorough peer review by experienced researchers in your field

- rapid publication on acceptance

- support for research data, including large and complex data types

- gold Open Access which fosters wider collaboration and increased citations

- maximum visibility for your research: over $100 \mathrm{M}$ website views per year

At $\mathrm{BMC}$, research is always in progress.

Learn more biomedcentral.com/submissions 